Diabetologia 10, $439-447(1974)$

(C) by Springer-Verlag 1974

\title{
Localization of Insulin on Fat Cell Ghosts by Ferritin Labelled Insulin Antibodies
}

\author{
E.A. Siess, M.-L. Nestorescu* and O.H. Wieland \\ Forschergruppe Diabetes, Munich and Klinisch-Chemisches Institut, Krankenhaus München-Schwabing, \\ Federal Republic of Germany
}

Received: February 26, 1974, and in revised form: June 4, 1974

\begin{abstract}
Summary. The localization of insulin on the surface of fat cell ghosts, incubated at physiological concentrations of the hormone, was tested with ferritin labelled insulin antibodies. Insulin binding sites, as revealed by this approach, were found to be uniformly distributed around ghost membranes. About $20 \%$ of the number of vesicles or $15 \%$ of the membrane surface area of a ghost preparation was tagged with ferritin. No ferritin labelling was observed when insulin was omitted from the reaction mixture or when it was replaced by proinsulin, insulin A and B chain, glucagon, ACTH or oxytocin. The membranes were also devoid of ferritin when the antiinsulin conjugate was substituted by unspecific $\gamma$-globulin conjugate. The insulin binding sites demonstrated by the immunoferritin
\end{abstract}

technique resembled the insulin receptor of fat cell membranes in so far as they showed trypsin sensitivity, heat lability and temperature dependency of insulin dissociation. From the distance between the ferritin particles and the membrane surface it appears that the insulin binding sites are located very close to or within the ghost membrane. The number of ferritin particles on individual membranes per unit area was higher than the number of insulin receptors calculated from the data of insulin binding studies on the basis of equal distribution of the receptor sites.

Key words : Localization, insulin, fat cell ghost, insulin receptor, ferritin-antiinsulin conjugate.
The interaction of insulin with receptor sites on fat cells and fat cell membranes has been established by measurements of the uptake of native $[5,6]$ or labelled insulin $[7-9,11,15,16,19,21]$. Although studies based on $\mathrm{I}^{125}$-insulin binding have yielded valuable information, this technique fails to answer questions pertaining to the distribution of the receptor sites on the membrane surface and the maintenance of receptor sites during the preparation of cells and membranes. Since labelling of antibodies with ferritin, as introduced by Singer [33], provides a means for detection of antigens at a molecular level, we attempted to answer the above questions by localizing receptor-bound insulin with ferritin-antiinsulin- $\gamma$-globulin conjugates.

\section{Materials and Methods}

Crystalline bovine insulin was kindly supplied by Dr. H. Schöne from Hoechst, Frankfurt (Germany). Proinsulin was a gift of Novo. Insulin A and B chains, and trypsin were purchased from Boehringer, Mannheim (Germany). Synthetic glucagon was kindly supplied by Prof. Dr. E. Wünsch, Max-Planck-Institut für Biochemie, München-Martinsried. Oxytocin and human serum albumin, Cohn fraction $V$, were products of Serva, Heidelberg (Germany). Bovine serum albumin was purchased from Behringwerke, Marburg (Germany).

Synthetic ACTH was obtained from Ciba and collagenase from Worthington. Horse spleen ferritin was

* Supported by a Fellowship from the Alexander von Humboldt-Stiftung, Bad Godesberg, Germany. prepared according to Kuhn et al. [22] or purchased from Merck-Schuchardt and purified by several recrystallisations according to [28]. Glutaraldehyde was obtained from Merck-Schuchardt and purified by distillation [12]. Fat cells were prepared according to Rodbell [30], except that the glucose concentration was $0.5 \mathrm{mM}$, using the epididymal fat pads from $120-$ $150 \mathrm{~g}$ male Sprague-Dawley rats, fed ad libitum. From these cells, ghosts were prepared according to Birnbaumer et al. [4]. The ghosts obtained from $3-4 \mathrm{~g}$ adipose tissue, corresponding to $1.8-2.4 \mathrm{mg}$ protein, were finally suspended in $1 \mathrm{ml}$ of $1 \mathrm{mM}$ sucrose containing $2 \%$ albumin.

The immunization of guinea pigs against insulin was performed as described earlier [31]. Control animals received the adjuvant and insulin-free solvent. Blood was withdrawn by heart puncture from the animals under $\mathrm{Nembutal}{ }^{\circledR}$ anesthesia. The $\gamma$-globulin fraction of the sera was obtained by precipitation with ammonium sulphate at $33 \%$ saturation (ice bath). Antiinsulin- $\gamma$-globulin and unspecific $\gamma$-globulin, respectively, were conjugated to ferritin as described earlier [32], except that $\left(\mathrm{NH}_{4}\right)_{2} \mathrm{SO}_{4}$, was removed by dialysis against $0.9 \% \mathrm{NaCl}, \mathrm{pH} 7$.

The insulin binding capacity of the purified ferritinantiinsulin- $\gamma$-globulin conjugate ( $=-$ specific conjugate) was measured radioimmunologically according to Berson and Yalow [3], except that bound and free insulin were separated according to Löffler and Weiss [23]. Conjugates showing a maximal insulin binding capacity of $35 \mathrm{mU} / \mathrm{ml}$ or higher were used.

Binding of insulin to fat cell ghosts was measured according to Crofford [5], except that the incubation was performed for 15 min at room temperature. Pro- 
tein was determined by the Lowry method [25], using bovine serum albumin as a standard.

\section{Standard Incubation Procedure}

The fat cell ghost suspension, $0.1 \mathrm{ml}$, was centrifuged for $0.5 \mathrm{~min}$ at $10,000 \mathrm{x} \mathrm{g}$ and the sediment was resuspended in $0.55 \mathrm{ml}$ of Krebs-Ringer-Bicarbonate (KRB)-1\% albumin-buffer, $\mathrm{pH} 7.4$, containing $55 \mu \mathrm{U}$ insulin, and incubated at room temperature for $10 \mathrm{~min}$.
After centrifugation, as above, the sediment was washed once with $0.5 \mathrm{ml}$ of ice-cold KRB-0.1\% albu$\min$ (KRBA). The sediment was suspended in $0.1 \mathrm{ml}$ of ferritin- $\gamma$-globulin conjugate and incubated for $1 \mathrm{~min}$ at room temperature. The ghosts were then collected by centrifugation as before and excess conjugate was removed by $3-4$ washings with $\mathrm{KRBA}, 0.5 \mathrm{ml}$ each. The ghosts were resuspended in each of the washings and the time required for the washing procedure was

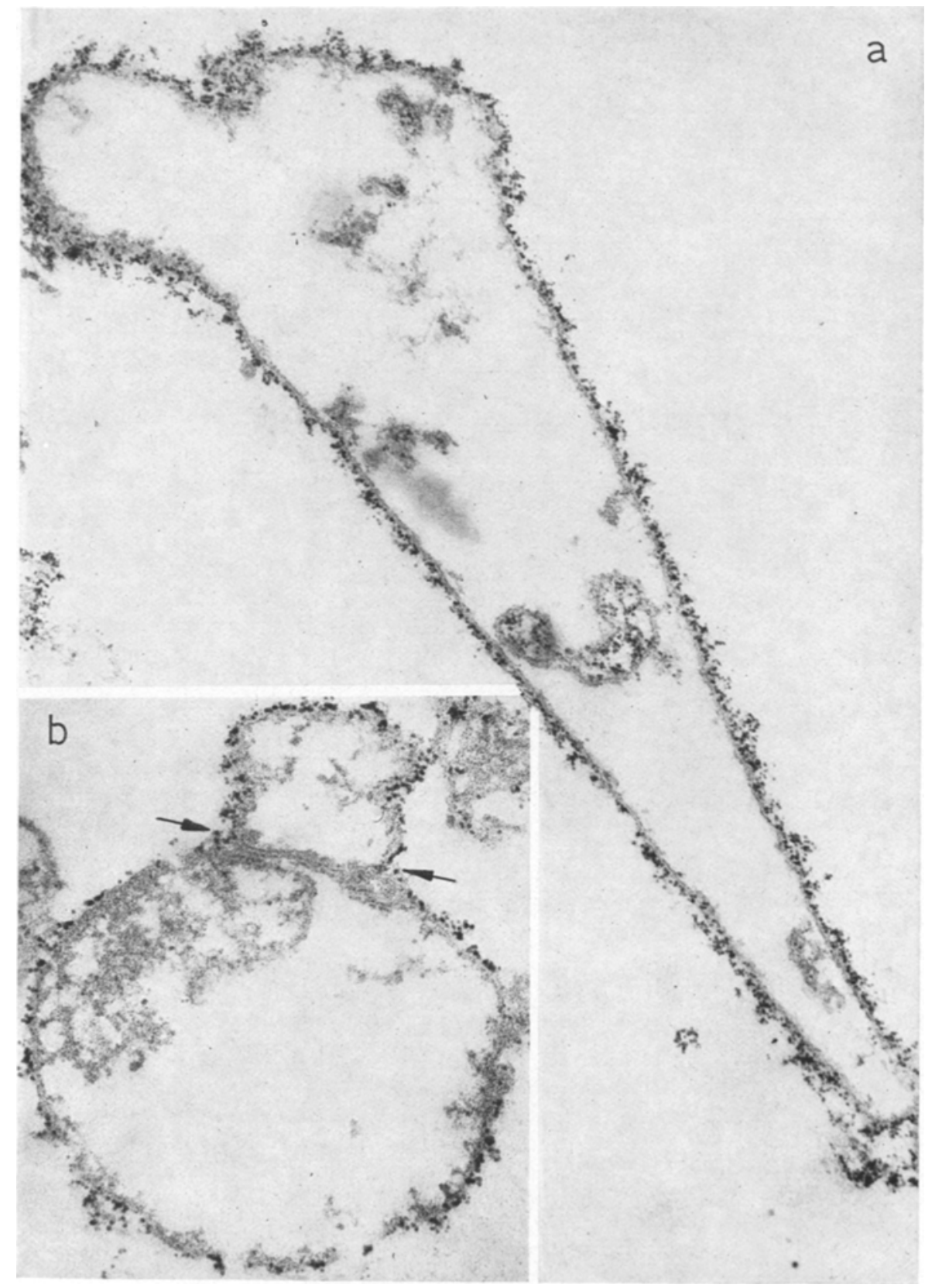

Fig. 1a and b. Electron micrographs of fat cell ghosts subjected to the "standard incubation procedure" showing dense labelling with ferritin-insulin-antibody conjugate. Ferritin is absent where ghosts are in contact (b) (arrows). a) $57000 \times$, b) $78000 \times$ 
about 5 min. After fixation in $2.5 \%$ glutaraldehyde in $0.15 \mathrm{M}$ sodium phosphate buffer, $\mathrm{pH} 7.2$, for $1 \mathrm{~h}$ in the cold, the ghosts were washed in the same buffer overnight, dehydrated in ethanol and propylenoxide and embedded in epon according to Luft [26]. Thin sections were cut on a LKB ultrotome III provided with a diamond knife, stained with $2 \%$ uranylacetate and lead citrate according to Reynolds [27], and examined in a Siemens Elmiskop 101.

\section{Control Experiments}

To prove the specificity of the immunoferritin localization of insulin, the standard incubation procedure was varied as follows: 1 . Ghosts were incubated in KRB- $1 \%$ albumin without insulin addition. 2 . The ferritin-antiinsulin- $\gamma$-globulin conjugate was replaced by an unspecific ferritin $\gamma$-globulin conjugate. 3 . Prior to the incubation with the ferritin-antiinsulin- $\gamma$-globulin conjugate, insulin treated ghosts were incubated

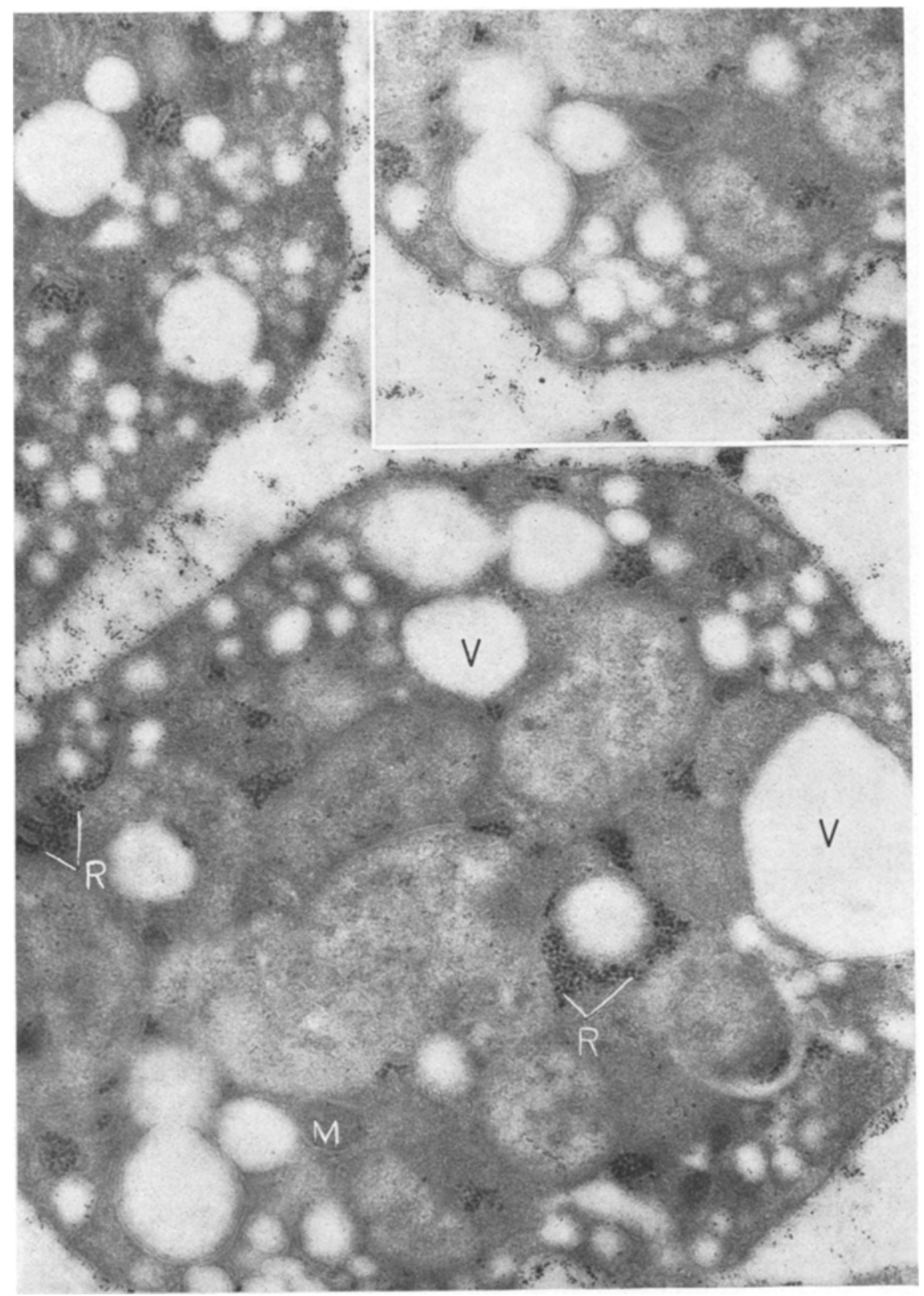

Fig. 2. Electron micrograph of ghosts containing cell constituents carried through the "standard incubation pro cedure". The ferritin particles are essentially confined to the ghost surface. $M=$ mitochondrion, $R=$ ribosomes, $\mathrm{V}=$ vacuoles, presumably due to lipid extraction. $36000 \times$ 
with unlabelled antiinsulin- $\gamma$-globulin $(60 \mu \mathrm{l}$, corresponding to $3 \mathrm{mgN} / \mathrm{ml}$ ) for $10 \mathrm{~min}$ and washed once with $0.5 \mathrm{ml} \mathrm{KRBA}$. 4 . Ghosts were trypsinised (final concentration of trypsin $100-500 \mu \mathrm{g} / \mathrm{ml}$ ) for $15 \mathrm{~min}$ at $37^{\circ} \mathrm{C}$ and washed once with KRBA prior to the standard procedure. 5. Insulin was replaced by proinsulin $(0.1 \mu \mathrm{g} / \mathrm{ml})$, insulin A and B chains $(0.5 \mu \mathrm{g} / \mathrm{ml})$, ACTH $(0.1 \mathrm{mg} / \mathrm{ml})$, glucagon $(50 \mu \mathrm{g} / \mathrm{ml})$, or oxytocin $(0.1 \mathrm{mg} / \mathrm{ml}) .6$. Ghosts were replaced by liver mitochondria or isolated tubules from rat kidney [17]. 7. Ghosts were heated at $56^{\circ} \mathrm{C}$ for $10 \mathrm{~min}$ prior to use in the standard incubation procedure. 8. Ghosts were processed as described under "standard incubation proce- dure" except that washing after insulin exposure was performed for $45 \mathrm{~min}$ at $37^{\circ} \mathrm{C}$ and $4^{\circ} \mathrm{C}$ respectively.

\section{Results}

Pilot experiments with isolated fat cells have shown that they often contained in their cytoplasm numerous, randomly distributed black granules of unknown origin. This phenomenon, earlier described by Williamson [34], was not observed with fat cell ghosts. Therefore, in order to avoid interference with ferritin localization, further studies were performed on fat cell ghosts.

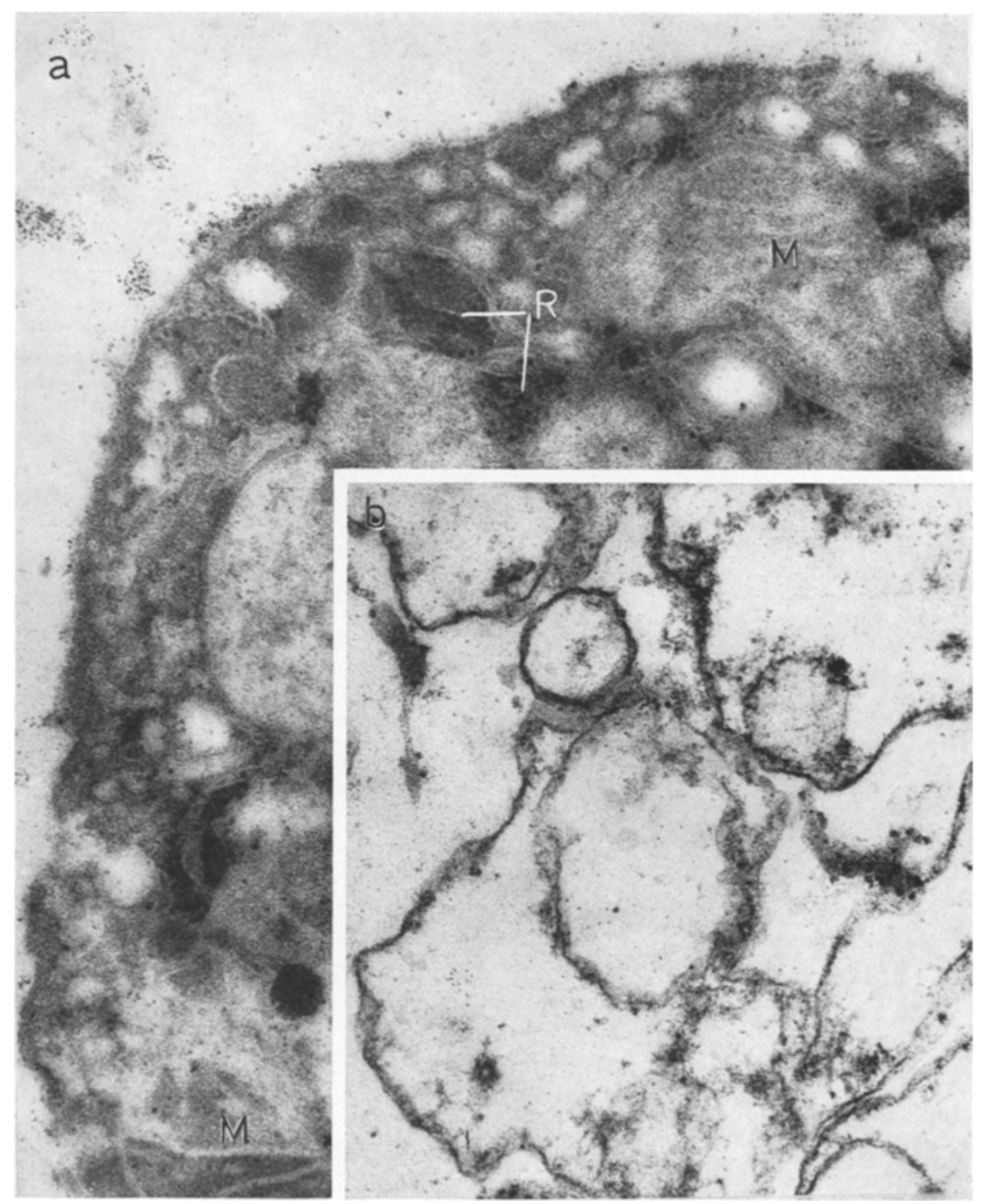

Fig. 3. Electron micrographs of ghosts from control incubations a) Insulin was replaced by proinsulin, b) unlabelled insulin antibody was applied prior to the ferritin labelled insulin antibody as described under "Methods". Albeit fields of the sections with the highest ferritin contamination. were selected, the label is virtually absent from the membranes. $\mathrm{M}=$ mitochondrion, $\mathrm{R}=$ ribosomes. $50000 \times$ 
Rodbell ghosts examined without incubation appeared as nearly empty vesicles of various size and form, with variable amounts of a filamentous material of low electron density attached to the inner surface of the surrounding membrane (see Figs. 1, 5, 6). This type of ghost has also been described by Angel and Farkas [2]. In some experiments a more cell-like type of ghosts was obtained, showing cell constituents such as nucleus, mitochondria and ribosomes (see Figs. 2, $3 a)$. The incubation of ghosts in the presence or absence of insulin $(100 \mu \mathrm{U} / \mathrm{ml})$ for $20 \mathrm{~min}$ at room tem- perature caused no visible change in their ultrastructure.

Ghosts incubated with insulin at a concentration of $100 \mu \mathrm{U} / \mathrm{ml}$ for $10 \mathrm{~min}$ at room temperature prior to the exposure to ferritin-antiinsulin conjugate (= specific conjugate) were studded with ferritin particles at their outer surface. Figs. 1 and 2 represent typical pictures obtained in 24 independent experiments.

Whether the insulin incubation was carried out over a period of $10 \mathrm{~min}$ or $25 \mathrm{~min}$ the same result was obtained. As judged from microphotographs, taken

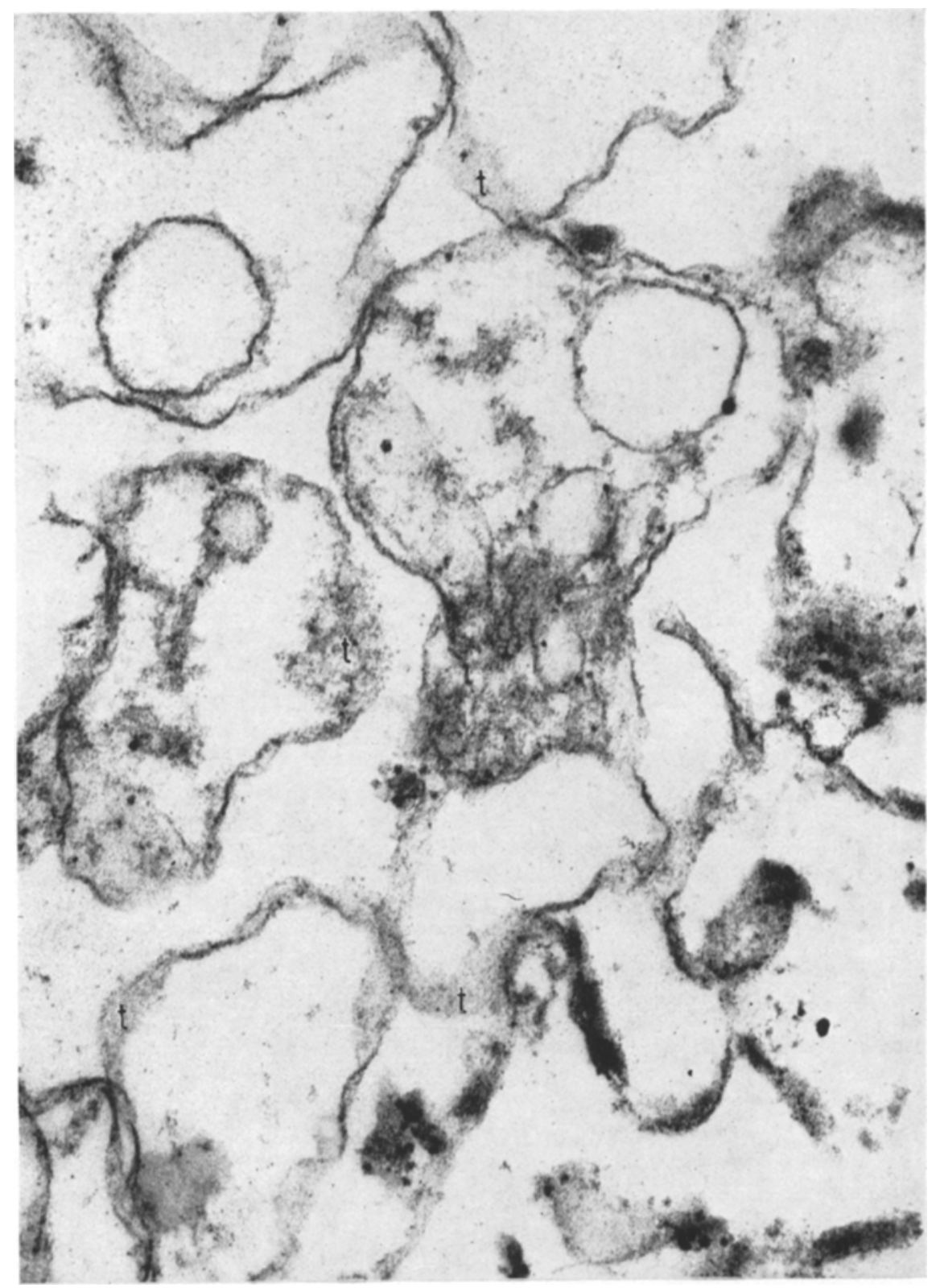

Fig. 4. Electron micrograph of a ghost preparation incubated for control without insulin prior to the incubation with specific conjugate. The membranes lack the ferritin label. $\mathbf{T}=$ tangentially sectioned parts of ghost membranes, $56000 \times$ 
from random fields of thin sections (see Figs. 5, 6), about $20 \%$ of the vesicles of a ghost preparation were tagged with ferritin. The evaluation according to Loud [24] showed that about $15 \%$ of all the surface area contained in a ghost preparation had reacted with ferritin labelled insulin antibodies. Membranes that were closely attached to each other were often found. As may be seen from Fig. 1b the "common" parts of replaced by proinsulin (see fig. $3 \mathrm{a}$ ), the $\mathrm{A}$ or $\mathrm{B}$ chain of insulin, oxytocin, glucagon or ACTH. On the other hand, ghosts incubated in $100 \mu \mathrm{U} / \mathrm{ml}$ insulin did not show the characteristic array of ferritin if the specific conjugate was replaced by an unspecific ferritin- $\gamma$ globulin conjugate ( 6 experiments), or by ferritin. Further proof for the specificity of the immunoferritin assay is provided by the fact that insulin loaded ghosts

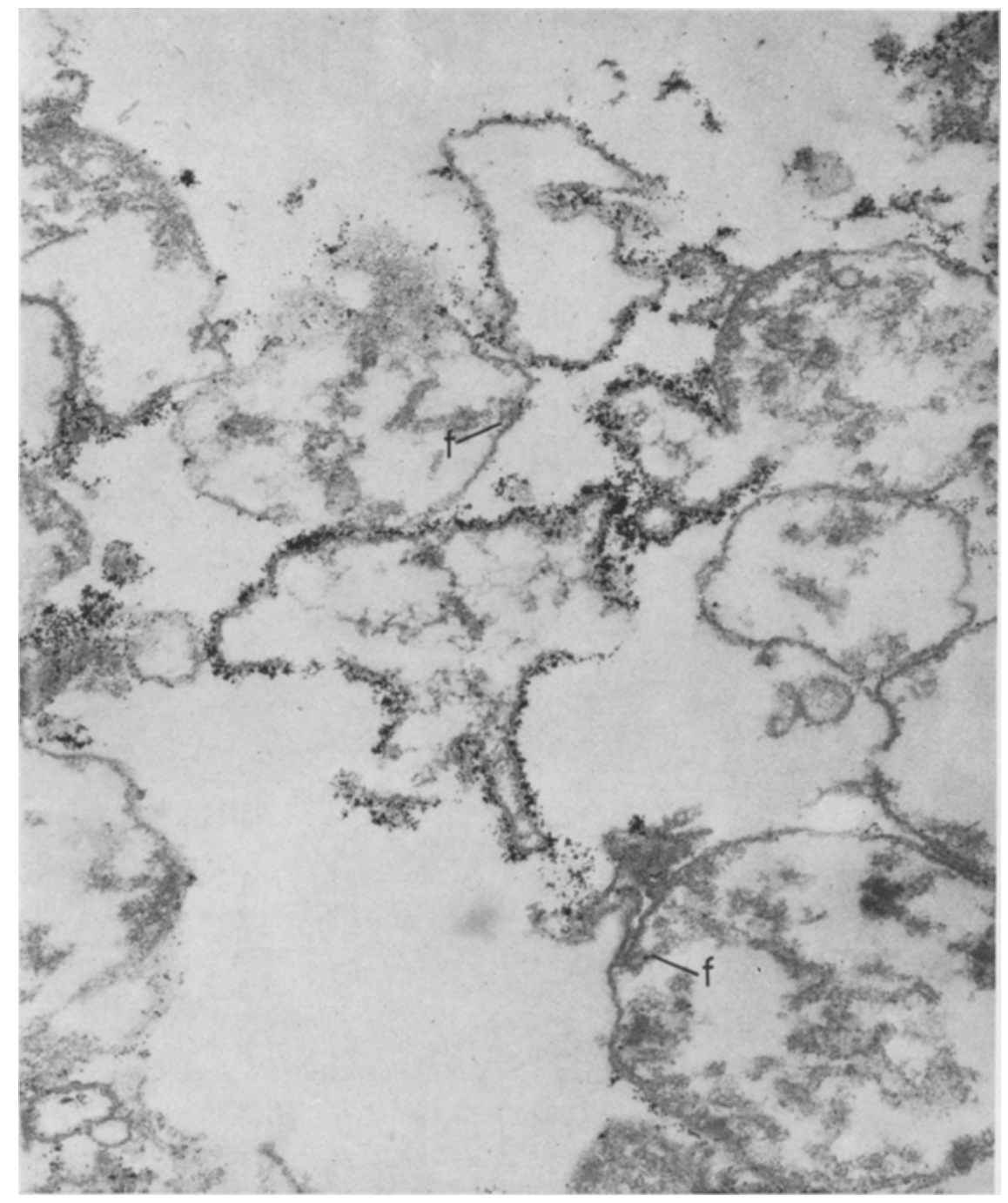

Fig. 5 and 6. Electron micrographs showing random fields of thin sections of ghost preparations carried through the "standard incubation procedure". The ferritin labelling is not homogeneous throughout the membrane population. $\mathrm{f}=$ filamentous material marking the inside of membranes. Fig. $521000 \times$, Fig. $627000 \times$

the membranes of such ghosts were free of ferritin. The number of ferritin bearing membranes was somewhat reduced by lowering the insulin concentration from $100 \mu \mathrm{U} / \mathrm{ml}$ to $20 \mu \mathrm{U} / \mathrm{ml}$; at $10 \mu \mathrm{U} / \mathrm{ml}$ insulin the ferritin label was observed occasionally (4 experiments).

Essentially no binding of the ferritin-antiinsulin conjugate occurred when insulin was omitted from the incubation mixture (12 experiments) (see Fig. 4), or
$(100 \mu \mathrm{U} / \mathrm{ml})$, treated with unlabelled insulin antibodies prior to the exposure to ferritin-labelled insulin antibodies, lacked the characteristic association of ferritin, as may be seen in Fig. 3b (4 experiments). In addition, the result was, as expected, negative, when using insulin insensitive structures, such as isolated rat kidney tubules or rat liver mitochondria instead of fat cell ghosts in the standard incubation procedure. In 
order to check whether the insulin assayed by the at. tachment of the ferritin-antiinsulin conjugate was bound to specific sites the ghost preparations were pretreated according to biochemical studies on the characterization of the insulin receptor. Since trypsination $[8,11,13,20,21]$, heating [9] and washing at elevated reduced (100 $\mu \mathrm{g}$ trypsin $/ \mathrm{ml})$ or abolished (500 $\mu \mathrm{g}$ trypsin/ml) the binding of specific conjugate (6 experiments). Trypsin was ineffectual, however, when added after insulin incubation together with the specific conjugate, indicating that trypsin did not interfere with the antibody-antigen reaction.

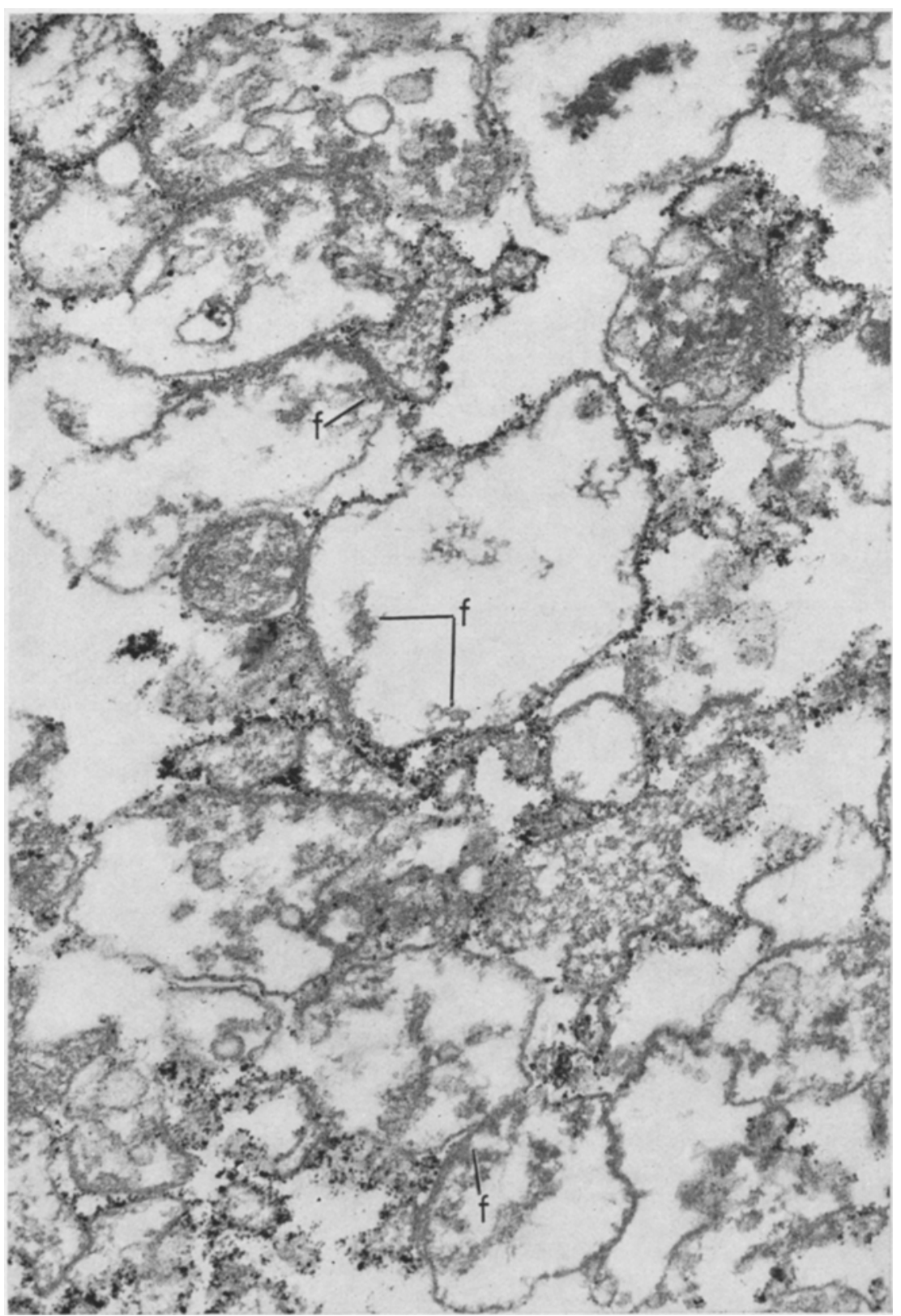

Fig. 6. Legend see Fig. 5

temperatures $[9,21]$ were found to decrease the binding of $\mathrm{I}^{125}$-insulin by the fat cell receptors, it was of interest to study the effect of these procedures on the binding of the ferritin-antiinsulin conjugate.

Treatment of our ghost preparations with trypsin prior to incubation at $100 \mu \mathrm{U} / \mathrm{ml}$ insulin markedly
According to Cuatrecasas the insulin receptor of fat cell membranes is destroyed by temperatures higher than $50^{\circ} \mathrm{C}[9]$. In agreement with this result the insulin uptake of our ghost preparations was reduced from $14.1 \pm 2.3 \mu \mathrm{U}(\mathrm{n}=5)$ per $100 \mu \mathrm{g}$ of ghost protein to $1.4 \pm 0.6 \mu \mathrm{U}(\mathrm{n}=5)$ by incubation at $56^{\circ} \mathrm{C}$ for 10 
min. Ghosts heated in this manner when used in the standard incubation procedure were devoid of ferritin particles, whereas the controls from the same batch of ghosts kept at room temperature were strongly positive ( 3 experiments).

A third approach to prove the specificity of the insulin binding sites revealed by the immuno-ferritin method was based on the temperature dependency of insulin dissociation from the receptor $[9,21]$. In accordance with the observation that $I^{125}$-insulin was removed from the receptor much faster at $37^{\circ} \mathrm{C}$ than at $4^{\circ} \mathrm{C}[9,21]$, appreciable amounts of ferritin-antiinsulin conjugate were found only in the sections taken from ghosts washed in the cold ( 2 experiments).

\section{Discussion}

The experiments summarized in this study provide the first attempt to localize insulin binding sites by electron microscopy. From the results presented it is reasonable to assume that the ferritin particles attached to the ghost membranes demonstrate bound insulin. The minimum distance between the electron dense cores of ferritin and the inner surfaces of the vesicles was found to be approximately $170 \AA$. After correction for the cell membrane thickness of $70 \AA$ and for the apoferritin coat of $25 \AA[10,14]$ a ferritinmembrane distance of about $75 \AA$ is obtained. With respect to this distance and the dimensions of $\gamma$-globulin of $240 \times 40 \AA[1,18,29]$ it would appear that the insulin binding sites are located very close to or within the ghost membrane.

To characterize the specificity of these binding sites their properties were compared with those properties found for the receptor of fat cell membranes in $I^{125}$. insulin binding studies. In accordance with these studies the sites of insulin binding, as assayed by the immunoferritin technique, proved to be trypsin sensitive. The amounts of trypsin necessary for complete abolition of ferritin labelling are in line with those used by Kono [20], Kono and Barham [21] and Fain and Loken [13] for maximal effect on $\mathrm{I}^{125}$-insulin binding to fat cells, but are considerably higher than the concentrations reported by Cuatrecasas [8] and by ElAllawy and Gliemann [11].

Also, with respect to the temperature dependency of insulin dissociation and heat lability, the insulin binding sites demonstrated by ferritin labelling resembled the $\mathrm{I}^{125}$-insulin receptor. The validity of the latter parameter for judging the specificity of insulin binding is limited, however, since heating caused a marked change of the ultrastructure of the ghosts: they appeared as a nearly homogeneous mass, lacking, to a large extent, distinct membrane profiles. So it is not clear whether the abolition of insulin uptake is due to heat lability of the binding sites or to the conglomeration of the membranes. Nevertheless, the coincidence in the lack of insulin uptake and ferritin-antiinsulin conjugate binding is notable.
Assuming an average thickness of the sections of $800 \AA$, a density of about 200 ferritin particles per $\mu^{2}$ of ghost surface was obtained. This value is much higher than the density of insulin receptor sites on fat cells calculated from insulin binding studies. According to the uptake of native insulin or $\mathbf{I}^{125}$-insulin by isolated fat cells $[5-8,15,16,21]$ or ghost membranes [9, 19] about 3-6 insulin molecules per $\mu^{2}$ cell surface area are bound. From the relation of the insulin uptake of our ghosts to the number of fat cells from which they originated, 10 insulin molecules per $\mu^{2}$ cell surface area could be expected when the cell diameter is $50 \mu \mathrm{m}$. This calculation is based on the assumptions (a) that all cells possess the same number of active binding sites, (b) that the binding sites are distributed equally on the cell surface and (c) that under given experimental conditions all of the binding sites are accessible to the hormone. The results of the ultrastructural localization, however, suggest that these suppositions may not be valid. The high percentage of membranes devoid of ferritin could indicate that the insulin receptor sites are distributed asymmetrically rather than equally on the fat cell membrane.

The possibility that the non-homogeneous ferritin labelling of the membrane preparations was caused by local insulin and/or conjugate deficiency cannot be excluded definitely. However, it seems to be unlikely, as densely labelled and unlabelled ghost membranes were closely adjacent, as may be seen in Figs. 5 and 6 . Moreover, within most of the vesicles filamentous material can be seen which provides a marker of the inside of the ghost membranes. Therefore the number of inside-out vesicles in the ghost preparations seems to be small and cannot explain the lack of ferritin labelling of a high portion of the vesicles. It would appear, therefore, that the density of receptor sites of individual membranes or parts of them is considerably higher than expected from average-data calculated from the results of binding studies. The evidence for this is provided by the specificity of the ferritin-labelled antibody for insulin, the use of physiological concentrations of native insulin, the abolition of specific conjugate binding by trypsin pretreatment or heating of the membranes, and the temperature dependent dissociation of insulin from the receptor sites.

Acknowledgment. We wish to thank Mrs. J. Langley for reading the manuscript. This work was supported by the Deutsche Forschungsgemeinschaft, Bad Godesberg, Germany.

\section{References}

1. Almeida, J., Cinader, B., Howatson, A.: The structure of antigen-antibody complexes. A study by electron microscopy. J. exp. Med. 118, 327-340 (1963)

2. Angel, A., Farkas, J.: Struetural and chemical compartments in adipose cells. In: Adipose tissue: Regulation and metabolic functions. pp. 152-161. Jeanrenaud, B., Hepp, D., (eds). Stuttgart: Thiome Verlag 1970 
3. Berson, S.A., Yalow, R.S.: Quantitative aspects of the reaction between insulin and insulin-binding antibody. J. clin. Invest. 38, 1996-2016 (1959)

4. Birnbaumer, L., Pohl, S.L., Rodbell, M.: Adenyl cyclase in fat cells. I. Properties and the effects of adre. nocorticotropin and fluoride. J. biol. Chem. 244, $3468-3476(1969)$

5. Crofford, O.B.: The uptake and inactivation of native insulin by isolated fat cells. J. biol. Chem. 243, 362$369(1968)$

6. Crofford, O.B., Minemura, T., Kono, T.: Insulinreceptor interaction in isolated fat cells. Adv. Enzyme Regul. 8, 219-238 (1970)

7. Cuatrecasas, P.: Insulin-receptor interactions in adipose tissue cells: Direct measurement and properties. Proc. nat. Acad. Sci. (Wash.) 68, 1264-1268 (1971)

8. Cuatrecasas, P.: Perturbation of the insulin receptor of isolated fat cells with proteolytic enzymes. Direct measurement or insulin-receptor interactions. J. biol. Chem. 246, 6522-6531 (1971)

9. Cuatrecasas, P.: Properties of the insulin receptor of isolated fat cell membranes. J. biol. Chem. 246, 7265$7274(1971)$

10. Easty, G.C., Mercer, E.H.: Electron microscopic studies of the antigen-antibody complex. Immunology 1, 353-364 (1958)

11. El-Allawy, R.M.M., Gliemann, J.: Trypsin treatment of adipocytes: Effect on sensitivity to insulin. Biochim. biophys. Acta (Amst.) 273, 97-109 (1972)

12. Fahimi, H.D., Drochmans, P.: Essais de standardisation de la fixation au glutaraldéhyde. I. Purification et détermination de la concentration du glutaraldéhyde. J. Microscopie 4, 725-736 (1965)

13. Fain, J.N., Loken, S.C.: Response of trypsin-treated brown and white fat cells to hormones. Preferential inhibition of insulin action. J. biol. Chem. 244, 3500$3506(\mathbf{1 9 6 9 )}$

14. Farrant, J.L.: An electron microscopic study of ferritin. Biochim. biophys. Acta (Amst.) 13, 569-576 (1954)

15. Freychet, P., Roth, J., Neville, D.M.: Monoiodoinsulin: Demonstration of its biological activity and binding to fat cells and liver membranes. Biochem. biophys. Res. Commun. 43, 400-408 (1971)

16. Gammeltoft, S., Gliemann, J.: Binding and degradation of ${ }^{125}$ I-labelled insulin by isolated rat fat cells. Biochim. biophys. Acta (Amst.) 320, 16-32 (1973)

17. Guder, W., Wiesner, W., Stukowski, B., Wieland, O.: Metabolism of isolated kidney tubules: Oxygen consumption, gluconeogenesis and the effect of cyclic nucleotides in tubules from starved rats. HoppeSeylers Z. physiol. Chem. 352, 1319-1328 (1971)

18. Hall, C.E., Nisonoff, A., Slayter, H.S.: Electron microscopic observations of rabbit antibodies. J. biophys. biochem. Cytol. 6, 407-412 (1959)

19. Hammond, J.M., Jarett, L., Mariz, I. K., Daughaday, W.H.: Heterogeneity of insulin receptors on fat cell membranes. Biochem. biophys. Res. Commun. 49, $1122-1128(1972)$

20. Kono, T.: Destruction and restoration of the insulin effector system of isolated fat cells. J. biol. Chem. 244, $5777-5784(1969)$

21. Kono, T., Barham, F.W.: The relationship between the insulin-binding capacity of fat cells and the cellular response to insulin. Studies with intact and trypsin-treated fat cells. J. biol. Chem. 246, 6210-6216 (1971)

22. Kuhn, R., Sörensen, N.A., Birkofer, L.: Ủber die Eisenproteide der Milz; der Bauplan des Ferritins. Ber. dtsch. chem. Ges. 73 B, $823-837$ (1940)

23. Löffler, G., Weiss, L.: Die radioimmunologische Bestimmung von Insulin. Mitt. Ges. Klin. Chem. Heft 3, $61-75$ (1971)

24. Loud, A.V.: A method for the quantitative estimation of eytoplasmic structures. J. Cell Biol. 15, 481$487(1962)$

25. Luft, J. H.: Improvements in epoxy resin embedding methods. J. biophys. biochem. Cytol. 9, 409-414 (1961)

26. Lowry, O.H., Rosebrough, N.J., Farr, A.L., Randall, R.J.: Protein measurement with the folin phenol reagent. J. biol. Chem. 193, 265-275 (1951)

27. Reynolds, E.S.: The use of lead citrate at high $\mathrm{pH}$ as an electronopaque stain in electron microscopy. $J$. Cell Biol. 17, 208-212 (1963)

28. Rifkind, R.A., Hsu, K.C., Morgan, C.: Immunochemical staining for electron microscopy. J. Histochem. Cytochem. 12, 131-136 (1964)

29. Robinson, J.P.: Electron microscopo studies of antigen-antibody complexes. J. molec. Biol. 17, 456-462 (1966)

30. Rodbell, M.: Metabolism of isolated fat cells. I. Ef. fects of hormones on glucose metabolism and lipolysis. J. biol, Chem. 239, 375-380 (1964)

31. Siess, E., Teinzer, A., Struck, E., Wieland, O.: Bildung eines insulinartigen Wirkstoffs durch die isolierte Rattenleber. Diabetologia 1, 21-27 (1965)

32. Siess, E., Wieland, O., Miller, F.: A simple method for the preparation of pure and active $\gamma$-globulin-ferritin conjugates using glutaraldehyde. Immunology 20, $659-665(1971)$

33. Singer, S.J.: Preparation of an electron-dense antibody conjugate. Nature 183, 1523-1524 (1959)

34. Williamson, J.R.: Adipose tissue. Morphological changes associated with lipid mobilisation. J. Cell Biol. 20, 57-74 (1964)

Dr. E. Siess

Forschergruppe Diabetes

Städt. Krankenhaus Schwabing

D-8000 München 40

Kölner Platz 1

Federal Republic of Germany 